\title{
Characterisation of Extracts and Anti-Cancer Activities of Fomitopsis pinicola
}

\author{
Karen S. Bishop \\ Discipline of Nutrition and Dietetics/Auckland Cancer Society Research Centre, School of Medical Sciences, \\ Faculty of Medicine and Health Sciences, University of Auckland, 85 Park Road, Grafton, Auckland 1023, \\ New Zealand; k.bishop@auckland.ac.nz; Tel.: +64-9-923-4471
}

Received: 23 January 2020; Accepted: 24 February 2020; Published: 26 February 2020

\begin{abstract}
Fomitopsis pinicola (Sw. Karst) is a common bracket fungus, with a woody texture. It is found predominantly in coniferous forests in temperate regions throughout Europe and Asia. Fomitopsis pinicola has been extensively used for medicinal purposes, particularly in Chinese and Korean traditional medicine. In this mini-review, the anti-cancer characteristics of F. pinicola extracts were investigated. In vitro experiments revealed the pro-apoptotic, anti-oxidant and anti-inflammatory properties of extracts, whilst two of three in vivo studies reported an inhibition of tumour growth and prolonged survival. Only studies wherein fungal specimens were sourced from Europe or Asia were included in this review, as samples sourced as F. pinicola from North America were probably not $F$. pinicola, but a different species. Although not one of the most revered fungal species, F. pinicola has been used as a medicinal fungus for centuries, as well as consumed as a health food supplement. To date, the results from only three in vivo studies, investigating anti-cancer properties, have been published. Further studies, using comprehensively identified specimens, are required to fully elucidate the anti-cancer properties of F. pinicola extracts.
\end{abstract}

Keywords: anti-cancer properties; extracts; Fomitopsis pinicola; location; medicinal history; sequence identification; taxonomy

\section{Introduction}

Fomitopsis pinicola (Sw. Karst), is a common woody fungus found in coniferous forests in temperate regions throughout Europe and Asia [1], including the Himalayas [2]. Numerous local names exist for F. pinicola, such as the Japanese name, which is Tsugasaruno-koshikake [3], and the English name of red-belted bracket fungus [4]. Fomitopsis pinicola is commonly known as a brown-rot fungus, characterised by bipolar sexual compatibility and the presence of the phenol oxidase, tyrosinase (with extracellular oxidase not present) [3]. It has been used in Chinese and Korean traditional folk medicine as an anti-inflammatory agent and for general well-being.

The fruiting body is fan shaped, has a hard, woody texture, can grow up to $40 \mathrm{~cm}$ in diameter (Figure 1), and is often referred to as the red belt conk. The fruiting body has a glossy appearance and can be red-brown or a lighter colour depending on the age of the specimen. It grows by adding an additional layer or tube annually. The fungus is saprobic and can also be parasitic, causing heart rot in living trees, and brown cuboidal rot in dead trees [2]. Decay fungi such as F. pinicola are often thought to be symbiotic and this could be due to the presence of fungi and nitrogen fixing bacteria at the same sites on fir trees [5]. In addition, they help circulate forest nutrients through the decay of dead tree trunks, although the brown rot residues can remain in the soil for extended periods before breaking down $[6,7]$. However, F. pinicola and other brown rot species can also contribute significantly to forestry loses, particularly at sites where the bark has been damaged as might occur when branches are removed. 
Fomitopsis pinicola, like many other fungi, are predominantly identified phenotypically, but require molecular biology techniques to confirm the identification. Internal spacer region (ITS) 2 sequencing is a suitable method that is routinely used for the correct identification of numerous species, including F. pinicola. Unfortunately, it can appear phenotypically similar to Ganoderma lingzhi and other species of the genus Fomitopsis, and therefore it is important to confirm the speciation of the specimen one is working with prior to publication.

A literature review of the anti-cancer properties of F. pinicola was performed using Embase, Web of Science and Google Scholar. Articles, published in English, where an in vitro and/or in vivo approach was implemented to investigate the anti-cancer properties of $F$. pinicola extracts, were included. Due to extensive fungal species misidentification [8], taxonomy and means of accurate identification of F. pinicola were also explored. Search terms included "Fomitopsis pinicola"+ "cancer" + "in vivo." Thereafter "anti-inflammatory" was substituted for "cancer", and an additional article was returned. In a similar manner "in vitro" was substituted for "in vivo", and "Fomitopsis pinicola" + "taxonomy" were also searched. Pearly growing was implemented. This article is not a systematic review and, together with the implementation of pearly growing, it was decided not to include numbers and justification for article inclusion and exclusion.

\section{The Taxonomy of F. Pinicola}

Fungi are poorly, and sometimes incorrectly, described [8]. More recently, sequence-based classification and identification (SBCI) has been used to detect and classify environmental fungi and also to confirm or dispute identification or classification of named specimens. The ITS of rRNA genes can be PCR-amplified and sequenced, and this method is commonly used for SBCI [8]. Further, $16 \mathrm{~S}$ rRNA sequences may also be used for this purpose, but it is regarded as less accurate than ITS sequencing, as the latter is less highly conserved and is therefore more likely to vary from one species to another [9]. To help avoid misidentifications, Edgar recommends the sequencing of two rather than one variable region, which could include V3, V4, V5 and ITS, or full-length 16s rRNA or large subunit rRNA genes [8,9]. With the integration and standardisation of stand-alone databases, and the incorporation of phylogenetic trees into pipelines used to identify or name specimens, data will be easier to incorporate into databases and therefore more likely to be deposited, and easier to access, thus strengthening the accuracy of fungal identification [8].

F. pinicola, an ancient polypore species, is classified according to the Integrated Taxonomic Information System [10] as follows:

Kingdom: Fungi

Division: Basidiomycota

Class: Agaricomycetes

Order: Polyporales

Family: Fomitopsidaceae

Genus: Fomitopsis

Species: F. pinicola

Fomitopsis pinicola was originally named in 1810 as Boletus pinicola by Swartz and then transferred to Fomitopsis by Petter Karsten in 1881 [11,12]. Fomitopsis pinicola (Swartz ex Fr.) P. Karst. (1881) was also named as Polyporus pinicola Fr. [3] before sequencing was used to clearly define the species. More recently, Binder et al. performed whole-genome sequencing using a shotgun approach, and classified F. pinicola in the antrodia clade [7]. 


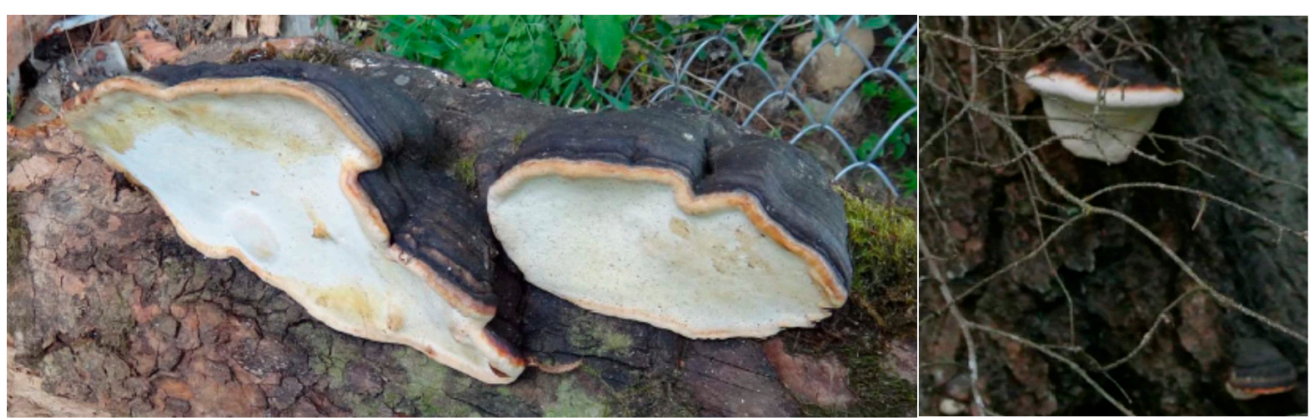

Figure 1. Basidomes of Fomitopsis pinicola in situ. These specimens were identified as F. pinicola by internal spacer region 2 sequencing [13]. (Permission was obtained from NZFocus to utilise this image.)

In 2016, Haight et al. reported on an investigation into the suspected F. pinicola complex [14]. Based on samples collected in North America, Europe and Asia and phenotypically identified as F. pinicola, four distinct species were identified, with only F. pinicola found in Europe and Asia. The other three species were found in different regions of North America [1,14]. For this reason, articles based on samples collected outside of Europe and Asia were not included in this review article.

F. pinicola is widely available and has been extensively used for medicinal purposes, particularly in Chinese traditional medicine [15]. However, the use of F. pinicola in Central European folk medicine has been largely forgotten [16]. Like many hardwood bracket fungi, it is believed that $F$. pinicola specimens were traditionally prepared for consumption as a soup/tea or in alcohol [15].

Although not one of the most revered fungal species, F. pinicola (Sw Karst) has been used as a medicinal fungus for centuries for the treatment of headaches, nausea and liver disease [16], as well as in health food supplements $[15,16]$.

\section{Active Ingredients}

For centuries, medicinal mushrooms have been used by various cultures to enhance health. Pharmacologic research into medicinal mushrooms, using in vitro, in vivo and clinical studies, has been used to identify several health benefits and their associated biological pathways [17]. However, very little research has been carried out on F. pinicola. A variety of extraction methods, whole extracts, fractions and compounds isolated from the mushroom, have been tested. Many of these are listed in Table 1. Studies carried out on specimens sourced from North America were not include (e.g., Liu et al. [18])

Although Table 1 includes the compounds that were detected in F. pinicola using different extraction methods, the anti-cancer activities were not assessed. Various phytochemicals have been shown to have specific anti-cancer properties, but it is generally accepted that these compounds probably act synergistically to achieve an anti-cancer effect [25]. Wang et al. identified ergosterol in a chloroform extract from F. pinicola and observed anti-cancer properties such as a pro-apoptotic and inhibition of migration effects [26]. Further, in a study published by Yoshikawa et al., fomitopinic acids and fomitosides inhibited cyclooxygenase (COX) 1 and 2 activity [23]. Although many of the compounds detected in F. pinicola have not been assessed in isolation, some of the compounds have been isolated from other species and found to have anti-cancer properties e.g., gallic acid [27]. Based on the available evidence, it is not possible to determine exactly which compounds exert the strongest anti-cancer properties, and further research is required. 
Table 1. Extraction method and fraction or compound detected from F. pinicola specimens.

\begin{tabular}{cccc}
\hline Citation & Extraction Method & Details of Method & Fraction/Compound/Concentration \\
\hline Gao et al. 2017, [19] & $\begin{array}{c}\text { 95\% ethanol or methanol for } 8 \\
\text { to } 10 \text { hours at room } \\
\text { temperature, evaporated and } \\
\text { washed in water, evaporated } \\
\text { and lyophilized. }\end{array}$ & $0.210 \mu \mathrm{M} \mathrm{GAE} / \mathrm{mg}$ \\
\cline { 2 - 4 } & Hot water & $\begin{array}{c}\text { Heated at } 100^{\circ} \mathrm{C} \text { for } 2 \text { to } 3 \\
\text { hours; } 4^{\circ} \mathrm{C} \text { overnight; } \\
\text { centrifuged and lyophilized. }\end{array}$ & $0.185 \mu \mathrm{M} \mathrm{GAE} / \mathrm{mg}$ \\
\cline { 2 - 4 } & Ethyl acetate & $\mathrm{NT}$. & $0.464 \mu \mathrm{M} \mathrm{GAE} / \mathrm{mg}$ \\
\hline Petroleum ether & $\mathrm{NT}$. & $0.389 \mu \mathrm{M} \mathrm{GAE} / \mathrm{mg}$ \\
\hline
\end{tabular}

Extracted three times with $50 \%$

ethanol or water for $24 \mathrm{~h}$. The

Wu et al. 2014, [20] Ethanol solutions were filtered, the

solvent removed by

NT

distillation and the sample was lyophilised.

The specimens were dried and

milled. Thereafter, the powder

was homogenised in $95 \%$

ethanol at $45^{\circ} \mathrm{C}$ and subjected

to ultrasonic- assisted

Gao et al. 2017, [19] Chloroform/ethanol

extraction. The extract was

fractionated with chloroform,

Ergosterol $(105 \mu \mathrm{g} / \mathrm{mg})$

homogenised in ethanol,

centrifuged and the

supernatant was filtered.

Submerged in whiskey or rice wine for six months, then freeze dried. The whiskey

Kao, 2019; Kao et al.

2018; Kao et al.

Whiskey/Rice wine

(ethanol)

extract was fractionated 1:1:1:1

(water: methanol: ethanol: chloroform).

Pachymic acid $(35.6 \mu \mathrm{g} / \mathrm{mg})$

Dehydroeburicoic acid $(2.5 \mu \mathrm{g} / \mathrm{mg})$.
2016, [13,21,22]

\begin{tabular}{l}
\hline \\
Yoshikawa et al. \\
2005, [23]
\end{tabular}

Keller et al. 1996, [24]
Dichloro-methane
Lanostenoid derivative. Seven triterpenes.
Aqueous fraction

Organic fraction

(56.4\% and $43.6 \%$ total weight respectively)

Submerged in $70 \%$ ethanol for six weeks and separated into

EtOAc and $\mathrm{H}_{2} \mathrm{O}$ portions.

Thereafter, the EtOAc extract was fractionated using silica gel column chromatography, and some fractions were

Lanostane triterpenes: Fomitopinic acid A and B

Lanostanoid glycosides: Fomitoside A-J

further fractionated using an HPLC.

$3 \alpha$-(4-car boxymethyl-3-hydroxy-

3-methylbutanoyloxy)-lanosta

-8,24-dien-21-oic acid,

polyporenic acid $\mathrm{C}$,

$3 \alpha$-acetyloxylanosta-8,24-dien-21-oic acid,

ergosta-7,22-dien-3/J-ol,

21-hydroxylanosta-8,24-dien- 3-one, pinicolic acid A,

trametenolic acid B

and pachymic acid21-oic acid

EtOAc—Ethyl acetate; GAE—gallic acid equivalents; HPLC—high-performance liquid chromatography; NT-not tested. 


\section{Anti-Cancer Activities}

Medicinal properties of mushrooms, based on hearsay, have been recorded for thousands of years-for example, Ganoderma lucidum (Lingzhi) has been used for general well-being since before the $5^{\text {th }}$ century by the Chinese [28]; Formes fomentarius has been used as a potent anti-inflammatory agent by the Greeks (450 BC) [29]; and puffball mushrooms of the genus Calvatia, have been used for centuries by Native Americans to promote wound healing [29]. More recently, medicinal mushrooms have been used as an adjuvant to cancer therapy to enhance the effects of treatment and for the alleviation of side effects from chemo- and radiation therapy (e.g., nausea) [30]. Furthermore, numerous clinical trials have been conducted to assess the potential anti-cancer properties of both in-house and commercially prepared medicinal mushrooms [30]. Fewer than ten in vitro studies on cancer cell lines have been published, but the number of in vivo publications on F. pinicola are even more limited.

\subsection{In Vitro Studies}

Numerous cell culture experiments have been used to investigate the anti-cancer properties of F. pinicola extracts. These studies have been outlined in Table 2 .

Table 2. In vitro studies in which the anti-cancer properties of F. pinicola were investigated.

\begin{tabular}{|c|c|c|c|c|c|c|}
\hline Citation & Cell Line* & $\begin{array}{l}\text { Cancer } \\
\text { Type }\end{array}$ & $\begin{array}{l}\text { Type of } \\
\text { Extract }\end{array}$ & $\begin{array}{l}\text { Cell Viability } \\
1000 \mu \mathrm{g} / \mathrm{ml}(\%)\end{array}$ & $\mathrm{IC}^{2} 0^{+}$ & Outcomes \\
\hline \multirow{14}{*}{$\begin{array}{l}\text { Choi et al. } \\
\text { 2007, [31] }\end{array}$} & N/A & N/A & $\begin{array}{c}\text { Not } \\
\text { specified }\end{array}$ & N/A & N/A & \multirow{14}{*}{$\begin{array}{c}\text { Increased anti-oxidant } \\
\text { activity }\end{array}$} \\
\hline & \multirow{2}{*}{$\mathrm{HeLa}$} & \multirow{2}{*}{ Cervix } & Water & 70.0 & NT & \\
\hline & & & Ethanol & 25.0 & NT & \\
\hline & \multirow{2}{*}{ HO-1 } & \multirow{2}{*}{ Melanoma } & Water & 98.0 & NT & \\
\hline & & & Ethanol & $40-45$ & NT & \\
\hline & SNU-354 & Liver & $\begin{array}{c}\text { Water } \\
\text { Ethanol }\end{array}$ & $\begin{array}{c}65.0 \\
35-45\end{array}$ & $\begin{array}{l}\text { NT } \\
\text { NT }\end{array}$ & \\
\hline & \multirow{2}{*}{ SNU-185 } & \multirow{2}{*}{ Liver } & Water & 60.0 & NT & \\
\hline & & & Ethanol & $35-45$ & NT & \\
\hline & \multirow{2}{*}{ SK-Hер3B } & \multirow{2}{*}{ Liver } & Water & $<82.0$ & NT & \\
\hline & & & Ethanol & $<50.0$ & NT & \\
\hline & \multirow{2}{*}{ Нер3В } & \multirow{2}{*}{ Liver } & Water & $<82.0$ & NT & \\
\hline & & & Ethanol & $<40.0$ & NT & \\
\hline & \multirow{2}{*}{$\mathrm{PLC} / \mathrm{RF} / 5$} & \multirow{2}{*}{ Liver } & Water & 95.0 & NT & \\
\hline & & & Ethanol & $<40.0$ & NT & \\
\hline \multirow{8}{*}{$\begin{array}{l}\text { Wu et al. } \\
2014,[20]\end{array}$} & \multirow{2}{*}{$\begin{array}{c}\text { S-180 } \\
\text { (mouse) }\end{array}$} & \multirow{2}{*}{ Sarcoma } & Water & 78.9 & NT & NT \\
\hline & & & Ethanol & 17.2 & NT & $\begin{array}{c}\text { Increased CC3, } \\
\text { APAF-1 and C-PARP }\end{array}$ \\
\hline & \multirow[b]{2}{*}{ HepG2 } & \multirow[b]{2}{*}{ Hepatoma } & Water & 96.6 & NT & \multirow{2}{*}{$\begin{array}{c}\text { NT } \\
\text { Increased CC3; NT; } \\
\text { NT }\end{array}$} \\
\hline & & & Ethanol & 28.7 & NT & \\
\hline & A549 & Lung & $\begin{array}{l}\text { Water } \\
\text { Ethanol }\end{array}$ & $\begin{array}{c}97.0 \\
7.1\end{array}$ & $\begin{array}{l}\text { NT } \\
\text { NT }\end{array}$ & $\begin{array}{c}\mathrm{NT} \\
\text { Increased CC3; NT; } \\
\text { NT }\end{array}$ \\
\hline & \multirow{2}{*}{ HCT-116 } & \multirow{2}{*}{ Colon } & Water & 62.5 & NT & \multirow{2}{*}{$\begin{array}{c}\mathrm{NT} \\
\text { Increased CC3; NT; } \\
\text { NT }\end{array}$} \\
\hline & & & Ethanol & 12.1 & NT & \\
\hline & MDA-MB-231 & Breast & $\begin{array}{l}\text { Water } \\
\text { Ethanol }\end{array}$ & $\begin{array}{l}60.1 \\
34.1\end{array}$ & $\begin{array}{l}\text { NT } \\
\text { NT }\end{array}$ & $\begin{array}{c}\mathrm{NT} \\
\text { Increased CC3; NT; } \\
\text { NT }\end{array}$ \\
\hline
\end{tabular}


Table 2. Cont.

\begin{tabular}{|c|c|c|c|c|c|c|}
\hline Citation & Cell Line* & $\begin{array}{l}\text { Cancer } \\
\text { Type }\end{array}$ & $\begin{array}{l}\text { Type of } \\
\text { Extract }\end{array}$ & $\begin{array}{c}\text { Cell Viability } \\
1000 \mu \mathrm{g} / \mathrm{ml}(\%)\end{array}$ & $\mathrm{IC} \mathrm{0}^{+}$ & Outcomes \\
\hline \multirow{6}{*}{$\begin{array}{l}\text { Gao et al. } \\
2017,[19]\end{array}$} & $\begin{array}{c}\text { S-180 } \\
\text { (mouse) }\end{array}$ & Sarcoma & FPKc & NT & 36.2 & $\begin{array}{c}\text { Induced late stage } \\
\text { apoptosis/decrease in } \\
\text { MMP/DNA } \\
\text { fragmentation }\end{array}$ \\
\hline & HL-60 & Leukemia & FPKc & NT & 41.0 & NT \\
\hline & K562 & Leukemia & FPKc & NT & 98.9 & NT \\
\hline & U937 & Leukemia & FPKc & NT & 34.9 & NT \\
\hline & SMMC-7721 & Hepatoma & FPKc & NT & 246.2 & NT \\
\hline & Eca-109 & Esophageal & FPKc & NT & 169.7 & NT \\
\hline \multirow{2}{*}{$\begin{array}{l}\text { Wang et al. } \\
\text { 2014, [26] }\end{array}$} & SW-480 & Colon & FPKc & NT & 190.3 & $\begin{array}{l}\text { Inhibits cell migration } \\
\text { and induce apoptosis. }\end{array}$ \\
\hline & SW-640 & Colon & $\begin{array}{l}\text { Ergosterol } \\
\text { FPKc }\end{array}$ & $\begin{array}{l}\text { NT } \\
\text { NT }\end{array}$ & 143.3 & $\begin{array}{c}\text { Induced cell apoptosis } \\
\text { NT }\end{array}$ \\
\hline \multirow[t]{2}{*}{$\begin{array}{l}\text { Kao et al. } \\
\text { 2018; Kao et } \\
\text { al. } 2016 \\
{[21,22]}\end{array}$} & PC3 & Prostate & WhE & $\mathrm{NC}$ & NT & $\begin{array}{c}\text { Upregulation of } \\
\text { pro-apoptotic genes, } \\
\text { and down-regulation } \\
\text { of anti-apoptotic } \\
\text { genes. Significant } \\
\text { changes in gene } \\
\text { expression associated } \\
\text { with cell-cycle } \\
\text { pathways, amongst } \\
\text { others. }\end{array}$ \\
\hline & DU145 & Prostate & WhE & $\mathrm{NC}$ & NT & $\begin{array}{l}\text { Significant changes in } \\
\text { gene expression } \\
\text { associated with } \\
\text { cell-cycle pathways, } \\
\text { amongst others. }\end{array}$ \\
\hline $\begin{array}{c}\text { Yoshikawa } \\
\text { et al. 2005, } \\
\text { [23] }\end{array}$ & N/A & N/A & $\begin{array}{l}\text { Ethanol } \\
\text { (fomitopinic } \\
\text { acid and } \\
\text { fomitosides) }\end{array}$ & & & $\begin{array}{l}\text { Anti-inflammatory } \\
\text { activity in response to } \\
\text { COX } 1 \text { and } 2 .\end{array}$ \\
\hline
\end{tabular}

\footnotetext{
* All cell lines are of human origin, unless otherwise stated. ${ }^{+}$IC50 was measured at $72 \mathrm{~h} \mathrm{in} \mu \mathrm{g} / \mathrm{ml}$. Abbreviations: APAF1-apoptotic peptidase activating factor 1; CC3 - cleaved caspase 3; COX-cyclooxygenase; C-PARP — cleaved-poly ADP ribose polymerase; FPKc - F. pinicola chloroform extract; IC50 - half maximal inhibitory concentration; MMP - mitochondrial membrane potential; N/A-not applicable; NC—not comparable (reported in $\mu \mathrm{l})$; NT—not tested/not reported; WhE—whiskey extract.
}

Hanahan and Weinberg described various hallmarks of cancer [32], which have enabled us to study the impact of extracts/compounds on these hallmarks (e.g., evasion of programmed cell death) and their related pathways, rather than on cancer directly. Underlying these hallmarks are mechanisms such as inflammation, genome instability and the creation of a tumour microenvironment [32]. Many of the in vitro studies outlined in Table 2 showed an increase in anti-oxidant activity [31], increase in apoptosis [19,26] or an upregulation of pro-apoptotic genes [21,22], and anti-inflammatory activity [23]. In addition, PARP, which is involved in DNA repair, genomic stability and programmed cell death, increased in response to treatment in a sarcoma cell line [20]. Cell cycle dysregulation is another hallmark of cancer [32] and may be a target of the mechanism of action of FPKc. This reasoning is supported by in vitro evidence showing the inhibition of cell proliferation; damage to cell membrane in sarcoma but not healthy cells; the triggering of S-phase cell cycle arrest; a decrease in MMP and release of mitochondrial cytochrome $C$ [19]. Together, these in vitro studies show that F. pinicola extracts/compounds have anti-cancer activities which warrant further investigation. 


\subsection{In Vivo Studies}

A small number of in vivo studies have been performed wherein the anti-cancer properties of F. pinicola were investigated. These studies are listed in Table 3. In two of the studies S-180 sarcoma cells were used to induce a xenograft $[19,20]$, and in the remaining study, PC3 prostate cancer cells were used [13]. The extracts (ethanol and chloroform) were both active against the sarcoma xenograft and inhibited growth, but the powder obtained from an F. pinicola ethanol extract showed no activity against the prostate cancer xenograft. The discrepancy in the results is thought to be due to the lack of bioavailability of the ethanol powder extract, as well as treatment at a later stage of disease [13].

Table 3. In vivo studies in which the anti-cancer properties of $F$. pinicola were investigated.

\begin{tabular}{|c|c|c|c|c|c|}
\hline Citation & Study Design & Treatment & $\begin{array}{l}\text { Type of } \\
\text { Extract }\end{array}$ & $\begin{array}{l}\text { Delivery of } \\
\text { Extract }\end{array}$ & Outcomes \\
\hline $\begin{array}{l}\text { Wu et al. 2014, } \\
\text { [20] }\end{array}$ & $\begin{array}{c}\text { Balb/c male } \\
\text { mice with S180 } \\
\text { xenograft }\end{array}$ & $\begin{array}{c}1.5-5 \mathrm{~g} / \mathrm{kg} ; \\
3 \text { and } 7 \\
\text { days prior } \\
\text { to xenograft }\end{array}$ & $\begin{array}{l}\text { Ethanol } \\
\text { extract }\end{array}$ & $\begin{array}{c}\text { Dietary } \\
\text { supplement }\end{array}$ & $\begin{array}{c}\text { Inhibition of tumour growth } \\
\text { (growth inhibitory ratio = } \\
54 \% \text { compared to control) } \\
\text { and prolonged survival }(40 \% \\
\text { survival in the control group, } \\
\text { and } 60 \%-70 \% \text { survival in the } \\
\text { intervention groups at } \\
\text { day } 30 \text { ). }\end{array}$ \\
\hline $\begin{array}{c}\text { Gao et al. 2017, } \\
\text { [19] }\end{array}$ & $\begin{array}{l}\text { ICR mice with } \\
\text { S180 xenograft }\end{array}$ & $\begin{array}{l}200 \mathrm{mg} / \mathrm{kg} ; \\
7 \text { days prior } \\
\text { to xenograft }\end{array}$ & FPKc & $\begin{array}{l}\text { Inoculated } \\
\text { subcutaneousl }\end{array}$ & $\begin{array}{l}\text { Inhibition of tumour growth } \\
\text { (inhibition rate }=47.7 \% \\
\text { compared to control) and } \\
\text { prolonged survival (control } \\
\text { lygroup-survival ranged from } \\
12 \text { to } 15 \text { days, and the } \\
\text { intervention group, survival } \\
\text { ranged from } 15 \text { to } 19 \text { days. }\end{array}$ \\
\hline Kao, 2019, [13] & $\begin{array}{l}\text { Rag-1 male } \\
\text { mice with PC3 } \\
\text { xenograft }\end{array}$ & $\begin{array}{c}1 \mathrm{~g} / \mathrm{kg} \text { once } \\
\text { the tumour } \\
\text { had reached } \\
200 \mathrm{~mm}^{3}\end{array}$ & $\begin{array}{l}\text { Ethanol-base } \\
\text { extract as } \\
\text { a powder }\end{array}$ & Oral gavage & $\begin{array}{l}\text { Dose was tolerated. No } \\
\text { noticeable effect. }\end{array}$ \\
\hline
\end{tabular}

Abbreviations: FPKc—chloroform extract of F. pinicola; ICR—institute of cancer research.

In addition to the three studies described in Table 3, Choi et al. also carried out an animal experiment whereby rats received $0.83 \mathrm{~g} / \mathrm{kg}$ of mushroom for two weeks following the administration of ethanol for two weeks [31]. Glutathione, glutathione peroxidase and catalase were all found to be significantly higher in the intervention versus the control group [31]. Glutathione is an anti-oxidant and, together with glutathione peroxidase and catalase, protects the cell against oxidative damage, and thus can exert an anti-tumour effect.

In a rat model with diabetes induced by streptozotocin, F. pinicola treatment decreased glucose levels, restored insulin levels to nearly normal, and pancreatic tissue damage was ameliorated [33]. The alkali extract was more effective than the water extract at reducing the harmful effects of streptozotocin induced diabetes [33]. Enhanced glucose uptake, and therefore hyperglycaemia, is a metabolic characteristic of cancer cells, and therefore the link between diabetes and cancers [34] is not surprising. Although the in vivo study by Lee et al. focused on the impact of F. pinicola extracts on diabetes, the benefits could be extrapolated to the treatment of cancers. This hyperglycaemic effect, in the context of cancers, should be investigated further.

\section{Limitations}

The most obvious limitation of this review is the lack of certainty surrounding the identity of the specimens used in the studies we discuss. For example, Gao et al. 2017 state that F. pinicola is 
traditionally categorized as Reishi [19], yet Reishi is identified as Ganoderma lucidum (Lingzhi) [28]. It is therefore unclear as to whether Gao et al. studied G. lucidum or F. pinicola and the method of species identification is not stated.

Another limitation includes the small number of in vivo studies performed. The fact that only three in vivo studies have been carried out, whereby the anti-cancer properties of F. pinicola were investigated, indicates the paucity of data and the need to carry out further studies in different cancer models.

\section{Conclusions}

In conclusion, further research is required to characterise the anti-cancer activities of F. pinicola as there is a paucity of data, particularly from in vivo and clinical studies. It would be useful to identify the bioactive components of F. pinicola and build on the research performed by Wang et al. and Gao et al. $[19,26]$. In particular, care must be taken to correctly identify each specimen using molecular techniques, prior to experimentation. Like many food components, F. pinicola has the potential to reduce the risk of disease. The advantage of investigating the anti-cancer benefits of F. pinicola is that the mushroom is not toxic as shown by anecdotal evidence over centuries, as well as in vivo studies. In addition, it is widely available and is affordable.

Funding: This research received no external funding.

Acknowledgments: Proof reading by Renee Alumasa is acknowledged and appreciated.

Conflicts of Interest: The author declares no conflict of interest.

\section{References}

1. Haight, E.J.; Nakasone, K.K.; Laursen, A.G.; Redhead, A.S.; Taylor, L.D.; Glaeser, A.J. Fomitopsis mounceae and F. schrenkii-two new species from North America in the F. pinicola complex. Mycologia 2019, 111, 339-357. [CrossRef] [PubMed]

2. Bakshi, B.E. Diseases and decays of conifers in the Himalayas-abstract. Indian For. 1955, 81, 779-797.

3. Yokoyama, A.; Natori, S.; Aoshima, K. Distribution of Tetracyclic Triterpenoids of Lanostane Group and Sterols in Higher Fungi Especially of Polyporaceae and Related Families. Phytochemistry 1975, 14, 487-497. [CrossRef]

4. British Mycological Society. English Names for Fungi. Available online: https://www.britmycolsoc.org.uk/ library/english-names (accessed on 7 October 2019).

5. Balandreau, J. Ecological Factors and Adaptive Processes in N-2-Fixing Bacterial-Populations of the Plant Environment. Plant Soil 1986, 90, 73-92. [CrossRef]

6. Gilbertson, R.L. North American wood-rotting fungi that cause brown rots. Mycotaxon 1981, 12, $372-416$. [CrossRef]

7. Binder, M.; Justo, A.; Riley, R.; Salamov, A.; Lopez-Giraldez, F.; Sjökvist, E.; Larsson, K.H. Phylogenetic and phylogenomic overview of the Polyporales. Mycologia 2013, 105, 1350-1373. [CrossRef]

8. Hibbett, D.; Abarenkov, K.; Kõljalg, U.; Öpik, M.; Chai, B.; Cole, J.; Herr, J.R. Sequence-based classification and identification of Fungi. Mycologia 2016, 108, 1049-1068.

9. Edgar, R.C. Accuracy of taxonomy prediction for 16S rRNA and fungal ITS sequences. PeerJ 2018, 6, e4652. [CrossRef]

10. ITIS. Available online: https://www.itis.gov/ (accessed on 7 October 2019).

11. Karsten, P. Meddelanden af Societatis pro Fauna et Flora Fennica. In Symbolae Ad Mycologiam Fennicam VIII; 1881; Volume 6, pp. 7-12, (In Latin), Cited in Binder et al. Available online: https://www.biodiversitylibrary. org/item/38778\#page/7/mode/1up (accessed on 7 October 2019).

12. Cooke. Studies in Forest Pathology II. The Biology of Fomes pinicola (SW). In Department of Biology; University of Toronto: Toronto, ON, Canada, 1929; p. 80.

13. Kao, C.H. An Investigation into the Potential Anti-Cancer Activities of an Extract from a Himalayan Fungus. Ph.D. Thesis, University of Auckland, New Zealand, 2019. 
14. Haight, J.E.; Laursen, G.A.; Glaeser, J.A.; Taylor, D.L. Phylogeny of Fomitopsis pinicola: A species complex. Mycologia 2016, 108, 925-938. [CrossRef]

15. Dresch, P.; Rosam, K.; Grienke, U.; Rollinger, J.M.; Peintner, U. Fungal strain matters: colony growth and bioactivity of the European medicinal polypores Fomes fomentarius, Fomitopsis pinicola and Piptoporus betulinus. AMB Express 2015, 5, 4. [CrossRef]

16. Grienke, U.; Zöll, M.; Peintner, U.; Rollinger, J.M. European medicinal polypores-A modern view on traditional uses. J. Ethnopharmacol. 2014, 154, 564-583. [CrossRef] [PubMed]

17. Lindequist, U.; TNiedermeyer, H.J.; Jülich, W.D. The Pharmacological Potential of Mushrooms. Evid. Based Complementary Altern. Med. 2005, 2, 285-299. [CrossRef] [PubMed]

18. Liu, X.T.; Winkler, A.L.; Schwan, W.R.; Volk, T.J.; Rott, M.; Monte, A. Antibacterial compounds from mushrooms II: lanostane triterpenoids and an ergostane steroid with activity against Bacillus cereus isolated from Fomitopsis pinicola. Planta Med. 2010, 76, 464-466. [CrossRef] [PubMed]

19. Gao, Y.; Wang, P.; Wang, Y.; Wu, L.; Wang, X.; Zhang, K.; Liu, Q. In Vitro and In Vivo Activity of Fomitopsis Pinicola (Sw. Ex Fr.) Karst Chloroform (Fpkc) Extract against S180 Tumor Cells. Cell. Physiol. Biochem. 2017, 44, 2042-2056. [CrossRef]

20. Wu, H.T.; Lu, F.H.; Su, Y.C.; Ou, H.Y.; Hung, H.C.; Wu, J.S.; Chang, C.J. In vivo and in vitro anti-tumor effects of fungal extracts. Molecules 2014, 19, 2546-2556. [CrossRef]

21. Kao, C.; Bishop, K. Corrigendum. Genom. Insights 2018, 11. [CrossRef]

22. Kao, C.H.; Bishop, K.S.; Xu, Y.; Han, D.Y.; Murray, P.M.; Marlow, G.J.; Ferguson, L.R. Identification of Potential Anticancer Activities of Novel Ganoderma lucidum Extracts Using Gene Expression and Pathway Network Analysis. Genom. Insights 2016, 9, 1-16.

23. Yoshikawa, K.; Inoue, M.; Matsumoto, Y.; Sakakibara, C.; Miyataka, H.; Matsumoto, H.; Arihara, S. Lanostane Triterpenoids and Triterpene Glycosides from the Fruit Body of Fomitopsis pinicola and Their Inhibitory Activity against COX-1 and COX-2. J. Nat. Prod. 2005, 68, 69-73. [CrossRef]

24. Keller, E.T.; Chang, C.; Ershler, W.B. Inhibition of NFkM activity through maintenance of IkB $\alpha$ levels contributes to dihydrotestosterone-mediated repression of the interleukin-6 promoter. J. Biol. Chem. 1996, 271, 26267-26275. [CrossRef]

25. Juge, N.; Mithen, R.F.; Traka, M. Molecular basis for chemoprevention by sulforaphane: a comprehensive review. Cell. Mol. Life Sci. Cmls 2007, 64, 1105-1127. [CrossRef]

26. Wang, Y.; Cheng, X.; Wang, P.; Wang, L.; Fan, J.; Wang, X.; Liu, Q. Investigating Migration Inhibition and Apoptotic Effects of Fomitopsis pinicola Chloroform Extract on Human Colorectal Cancer SW-480 Cells. PLoS ONE 2014, 9, e101303. [CrossRef] [PubMed]

27. Giftson, J.S.; Jayanthi, S.; Nalini, N. Chemopreventive efficacy of gallic acid, an antioxidant and anticarcinogenic polyphenol, against 1,2-dimethyl hydrazine induced rat colon carcinogenesis. Investig. New Drugs 2010, 28, 251-259. [CrossRef] [PubMed]

28. Wachtel-Galor, S.; Yuen, J.; Bushwell, J.; Benzie, I. Ganoderma Lucidum (Lingzhi or Reishi): A Medicinal Mushroom. In Herbal Medicine: Biomolecular and Clinical Aspects; Benzie, I.F.F., Wachtel-Galor, S., Eds.; CRC Press: Boca Raton, FL, USA, 2011; pp. 53-76.

29. Stamets, P.; Zwickey, H. Medicinal Mushrooms: Ancient Remedies Meet Modern Science. Integr. Med. A Clin. J. 2014, 13, 46-47.

30. Patel, S.; Goyal, A. Recent developments in mushrooms as anti-cancer therapeutics: a review. 3 Biotech 2012, 2, 1-15. [CrossRef]

31. Choi, D.; Park, S.S.; Ding, J.L.; Cha, W.S. Effects of Fomitopsis pinicola extracts on antioxidant and antitumor activities. Biotechnol. Bioprocess Eng. 2007, 12, 516. [CrossRef]

32. Hanahan, D.; Robert, A. Weinberg, Hallmarks of Cancer: The Next Generation. Cell 2011, 144, 646-674. [CrossRef] 
33. Lee, S.I.; Kim, J.S.; Oh, S.H.; Park, K.Y.; Lee, H.G.; Kim, S.D. Antihyperglycemic effect of Fomitopsis pinicola extracts in streptozotocin-induced diabetic rats. J. Med. Food 2008, 11, 518-524. [CrossRef]

34. Garcia-Jimenez, C.; García-Martínez, J.M.; Chocarro-Calvo, A.; De la Vieja, A. A new link between diabetes and cancer: enhanced WNT/ $\beta$-catenin signaling by high glucose. J. Mol. Endocrinol. 2014, 52, R51-R66. [CrossRef] 